\author{
ANDRZEJ CHAJBOWICZ \\ ORCID: 0000-0003-1863-1786 \\ Uniwersytet Wrocławski \\ Instytut Nauk Administracyjnych \\ Zakład Porównawczej Administracji Publicznej
}

\title{
ADMINISTRACJA WOBEC ZMIAN KLIMATU (PROLEGOMENA)
}

\begin{abstract}
Abstrakt: Globalne ocieplenie jest uznawane za największy problem, przed którym stoi ludzkość w XXI wieku. Regulacje prawne mające na celu zapobieżenie kryzysowi klimatycznemu lub redukujące jego skutki zaczęły pojawiać się od lat dziewięćdziesiątych ubiegłego wieku. Związane jest to z działalnością Międzyrządowego Panelu do spraw Zmian Klimatu (IPCC), która doprowadziła do przyjęcia w 1992 roku Ramowej Konwencji Narodów Zjednoczonych w sprawie Zmian Klimatu, uzupełnionej w 1997 roku przez protokół z Kioto. Międzynarodowe, europejskie i krajowe regulacje prawne mające na celu ochronę klimatu implikują cały szereg nowych zadań dla władz publicznych. Wpływają również na strukturę administracji publicznej, powodując konieczność tworzenia nowych, wyspecjalizowanych organów.
\end{abstract}

Słowa kluczowe: administracja publiczna, zmiany klimatu, globalne ocieplenie, konwencja klimatyczna

Drugą połowę XX wieku, zwłaszcza od przełomu lat sześćdziesiątych i siedemdziesiątych, bez wątpienia można nazwać wzmożonym okresem wzrostu świadomości środowiskowej — i to w skali globalnej. Przez długie dziesięciolecia kwestie ochrony środowiska były sprowadzane w poszczególnych państwach do działań sektorowych, związanych z ochroną typowych elementów środowiska przyrodniczego, takich jak fauna, flora, wody, lasy, kopaliny, a regulacje prawne, obok typowych funkcji ochronnych, miały na celu uporządkowanie korzystania z nich jako zasobów wykorzystywanych w poszczególnych gałęziach gospodarki.

Człowiek od zawsze oddziaływał na środowisko, dokonując w nim zmian dyktowanych przede wszystkim względami czysto utylitarnymi. Świadomość jednoczesnej konieczności jego ochrony pojawiła się stosunkowo późno, bo dopiero w XIX wieku, i sprowadzała się do koncepcji konserwatorskiej ochrony przyro- 
dyํ. Gwałtowny rozwój przemysłu, jaki miał miejsce od początku XX stulecia, oraz idąca za nim dewastacja środowiska, jak zauważył Jan Boć, nie zdołały jednak doprowadzić do przemian w świadomości ludzkiej, które miałyby charakter uniwersalnego katalogu zasad decydujących o sposobie i zasięgu dopuszczalnego korzystania ze środowiska i o granicach jego ochrony ${ }^{2}$.

Przełom w świadomości środowiskowej o charakterze globalnym nastąpił dopiero pod koniec lat sześćdziesiątych ubiegłego stulecia pod wpływem działalności prowadzonej przez wyspecjalizowane agendy Organizacji Narodów Zjednoczonych, zwłaszcza UNESCO, FAO i WHO. W dyskusji podczas XXIII sesji Zgromadzenia Ogólnego Narodów Zjednoczonych w 1968 roku stwierdzono,

że po raz pierwszy w historii ludzkości pojawił się kryzys o zasięgu ogólnoświatowym, obejmujący zarówno kraje rozwinięte, jak i rozwijające się — kryzys dotyczący stosunku człowieka do środowiska. Oznaki zapowiadające ten kryzys były widoczne od dawna — eksplozje demograficzne, niedostateczna integracja stale rozwijającej się techniki z wymogami środowiska, bezplanowy rozwój stref miejskich, zmniejszenie się terenów wolnych i zwiększone niebezpieczeństwo wyginięcia wielu form życia roślinnego i zwierzęcego ${ }^{3}$.

Całość zaś sprowadzała się do konstatacji, że przyszłe życie na Ziemi może być zagrożone.

Dobitnie tezę tę wyartykułował ówczesny Sekretarz Generalny ONZ, pochodzący z Birmy U Thant, w przedstawionym w 1969 roku raporcie Człowiek i jego środowisko, który przeszedł do historii jako „raport U Thanta”. Paradoksem jest, że ponad pięćdziesiąt lat później, w XXI wieku, owo przesłanie jest nadal aktualne — mimo olbrzymiego postępu, jaki dokonał się w dziedzinie nauki, technologii przemysłowych, i mimo zmian, jakie zaszły w świadomości i wiedzy na temat realnych zagrożeń. A przecież w dzisiejszym świecie na zagadnienia ekologiczne (w języku potocznym rozumiane jako związane ze środowiskiem i jego ochroną) nie patrzymy tylko z perspektywy nauk ścisłych czy pod kątem regulacji prawnych, lecz także z punktu widzenia polityki, filozofii, etyki czy religii. Jak pisze Irena Grochowska, ,aspekt etyczno-filozoficzny w ochronie klimatu jest znaczący, gdyż człowiek jako osoba rozumna o wymiarze moralnym powinna mieć świadomość ciągle nowej odpowiedzialności za świat"4.

1 Zob. szerzej: J. Boć, K. Nowacki, E. Samborska-Boć, Ochrona środowiska, Wrocław 2005, s. 61 n.; Prawo ochrony środowiska, red. M. Górski, Warszawa 2018, s. 35 n.; P. Korzeniowski, Bezpieczeństwo ekologiczne jako instytucja prawna ochrony środowiska, Łódź 2012, s. 33 n.

2 J. Boć, K. Nowacki, E. Samborska-Boć, op. cit., s. 61. Pisząc o przesłankach ochrony środowiska, autorzy wymieniają przesłanki biologiczne, społeczne i ekonomiczne, jednak da się zauważyć nie tylko ich wzajemne powiązanie, ale także swoistą kolejność pojawiania się i rozwoju.

3 Cyt. za: ibidem, s. 69.

${ }^{4}$ Zmiany klimatu a społeczeństwo, red. L. Karski, I. Grochowska, Warszawa 2010, s. 5. Więcej: I. Grochowska, Benedykt XVI o powinności względem środowiska i integralnego rozwoju czlowieka i ludów, [w:] Zmiany klimatu a społeczeństwo..., s. 25 n.; eadem, Humanizacja w XXI wieku nowoczesnego podmiotu, „Studia Ecologiae et Bioethicae” 2004, nr 2, s. 177-178. Zob też: K. Najder-Stefaniak, Metanoia jako odpowiedź na etyczny wymiar kryzysu, [w:] Zmiany klimatu 
Aktualnie diagnozowany kryzys klimatyczny wydaje się być egzemplifikacją i kulminacją problemów współczesnego świata, a coraz bardziej powszechne staje się odczucie, że ludzkość znalazła się w punkcie zwrotnym ${ }^{5}$.

Klimat, mimo że jest pojęciem języka prawnego, nie ma definicji legalnej. Nie należy tego uznawać za błąd ustawodawcy, gdyż w prawie ochrony środowiska sensu largo (rozumianym jako system aktów normatywnych dotyczących środowiska i jego ochrony, a nie tylko sprowadzanym do nazwy ustawy) można wskazać wiele definicji będących mało udaną próbą adaptowania do języka prawnego pojęć sui generis należących do nauk przyrodniczych, technicznych czy społecznych. W sensie formalnym klimat stanowi jeden z elementów środowiska wymienionych w definicji środowiska w art. 3 pkt 39 ustawy z dnia 27 kwietnia 2001 roku Prawo ochrony środowiska ${ }^{6}$, zatem podlega ochronie prawnej, tak jak pozostałe elementy środowiska. Od razu trzeba zaznaczyć, że w sensie systemowym można wyodrębnić prawo ochrony klimatu ${ }^{7}$, należy jednak pamiętać, że jest ono częścią większej całości, jaką jest prawo ochrony powietrza będące od kilkudziesięciu lat jedną z regulacji sektorowych prawa ochrony środowiska (w Polsce przynajmniej od roku 1980, kiedy została przyjęta pierwsza ustawa środowiskowa, czyli ustawa z dnia 31 stycznia 1980 roku O ochronie i kształtowaniu środowiska ${ }^{8}$, lub nawet wcześniej, od roku 1966, czyli przyjęcia ustawy z dnia 21 kwietnia 1966 roku o ochronie powietrza ${ }^{9}$ ). Większość bowiem zjawisk, które w długiej perspektywie czasowej nazywamy klimatem, zachodzi w ziemskiej atmosferze (czyli powietrzu) i jest uzależniona od jej składu fizykochemicznego. Ze względu na przyjęte założenia tej pracy szczegółowe regulacje dotyczące ochrony powietrza zostaną, z uwagi na ich ilość i zróżnicowany charakter, pominięte.

Ochronę klimatu należy rozumieć w kontekście ochrony bezpieczeństwa, a więc jako jedno z podstawowych dóbr — zarówno w wymiarze jednostkowym, jak i społecznym. Chodzi tu o specjalistyczny ${ }^{10}$ rodzaj bezpieczeństwa, jakim jest

a spoleczeństwo..., s. $51 \mathrm{n}$. Bardzo mocno problemy środowiska w kontekście teologicznym zaakcentował papież Franciszek w encyklice Laudato si z 18 czerwca 2015 roku (tekst na stronie: www. vatican.va).

${ }^{5}$ Używając tego zwrotu, nawiązuje do tytułu książki M. Mesarovica i E. Pastela Ludzkość w punkcie zwrotnym. Drugi Raport dla Klubu Rzymskiego, Warszawa 1977, będącej diagnozą problemów ekologicznych, przed którymi stanął świat w latach siedemdziesiątych XX wieku, z którymi to czasem wiąże się początek globalnych działań na rzecz ochrony środowiska.

${ }^{6}$ Dz.U. z 2001 r. Nr 62, poz. 627 ze zm.

${ }^{7}$ L. Karski posługuje się pojęciem prawa zmian klimatu. Nie wydaje się to do końca trafne, gdyż regulacje prawne z tego obszaru nie wpływają na owe zmiany, lecz mają na celu ich powstrzymanie oraz minimalizację skutków. Zob. L. Karski, Istota prawa zmian klimatu - cel i klasyfikacja [w:] Zmiany klimatu a społeczeństwo..., s. $433 \mathrm{n}$.

8 Dz.U. z 1980 r. Nr 3, poz. 6 ze zm.

9 Dz.U. z 1966 r. Nr 14, poz. 87 ze zm.

10 Szerzej na ten temat: A. Chajbowicz, Bezpieczeństwo a pojęcia zbliżone, [w:] Bezpieczeństwo wewnętrzne $w$ działaniach terenowej administracji publicznej, red. A. Chajbowicz, T. Kocowski, Wrocław 2009, s. 37 n. 
bezpieczeństwo ekologiczne. W doktrynie prawa ochrony środowiska funkcjonuje co najmniej kilkanaście definicji tego pojęcia ${ }^{11}$. Na potrzeby niniejszego opracowania można przyjąć definicję Janiny Ciechanowicz-MacLean, która określa je jako

całkowitą likwidację lub zmniejszenie do minimum różnorodnych zagrożeń życia i zdrowia człowieka, których źródłem jest środowisko jego życia, biosfera. Są to zagrożenia, które powstają w środowisku w wyniku świadomego bądź nie w pełni świadomego działania samego człowieka i są wymierzone przeciwko niemu, przeciwko konkretnym populacjom. Są to więc zagrożenia ekologiczne o charakterze antropogenicznym ${ }^{12}$.

Osią konstrukcyjną regulacji prawnych dotyczących ochrony klimatu jest teza o ich antropogenicznym charakterze. Od razu trzeba dodać, że w niektórych środowiskach ta teza jest odrzucana a priori, bez refleksji nad jej naukowymi podstawami, a problematyka zmian klimatu, zwłaszcza w ostatnich latach, stała się mocno zideologizowana i upolityczniona.

Naukowa refleksja nad wpływem człowieka na system klimatyczny naszej planety sięga lat osiemdziesiątych ubiegłego stulecia. Oczywiście klimatolodzy, astrofizycy od lat prowadzili badania nad czynnikami kształtującymi klimat naszej planety, lecz dominował pogląd, że człowiek nie jest w stanie wpływać na zjawiska zachodzące w skali kosmicznej. Pierwszym zdiagnozowanym problemem w skali planetarnej była tak zwana dziura ozonowa, za której odkrywcę uważa się Joe Farmana, czyli ubywanie cząsteczek ozonu w wysokich warstwach ziemskiej atmosfery (tak zwanego ozonu stratosferycznego). Ozon stratosferyczny pełni rolę „filtra ochronnego" naszej planety, nie dopuszczając, by nadmierne ilości promieniowania słonecznego docierały na powierzchnię Ziemi, gdyż wiąże się to z degeneracją wszelkich organizmów żywych. Dość szybko okazało się, że winę za ubytek cząsteczek ozonu ponosi człowiek, produkując sztuczne gazy techniczne, tak zwane freony, powszechnie stosowane w lodówkach, urządzeniach klimatyzacyjnych, dezodorantach itp. Uwolniona do atmosfery cząstka gazu może w niej bardzo długo przebywać, nie wchodząc w reakcje z innymi substancjami. W końcu dociera do stratosfer i tam, pod wpływem promieniowania słonecznego, dokonuje się „konsumpcja” cząstki ozonu $\mathrm{O}_{3}$, która jest redukowana do zwykłego tlenu $\left(\mathrm{O}_{2}\right)$ - cząstka tlenu nie pełni jednak takiej funkcji, jak cząstka ozonu. Normatywną reakcją na zaistniały problem było przyjęcie w roku 1985 konwencji wiedeńskiej o ochronie warstwy ozonowej, która uzupełniona dwa lata później przez protokół montrealski zakazała uwalniania gazów technicznych do atmosfery, dopuszczając ich użycie jedynie w obiegu zamkniętym ${ }^{13}$. Skutkiem przyjęcia

11 Zob. P. Korzeniowski, op. cit., s. 47 n.

12 J. Ciechanowicz, Międzynarodowe prawo ochrony środowiska, Warszawa 1999, s. 46-47.

13 Artykuł 1 pkt 3 konwencji posługuje się pojęciem technologii alternatywnych, czyli takich, które umożliwiają redukcję lub wyeliminowanie emisji substancji mających lub mogących mieć negatywne skutki w warstwie ozonowej. 
konwencji było uchwalenie ustawy z dnia 15 maja 2015 roku o substancjach zubożających warstwę ozonową oraz niektórych fluorowanych gazach cieplarnianych $^{14}$. W powszechnej świadomości konwencja wiedeńska uchodzi za przykład jednego z niewielu aktów międzynarodowego prawa ochrony środowiska, który okazał się skuteczny, to znaczy osiągnięto zamierzony w akcie cel.

Jednak faktyczne działania w skali globalnej na rzecz ochrony klimatu wiążą się z utworzeniem w roku 1988 Międzyrządowego Panelu do spraw Zmian Klimatu (Intergovernmental Panel on Climate Change - IPCC) ${ }^{15}$. Panel został założony przez dwie wyspecjalizowane organizacje Narodów Zjednoczonych: Światową Organizację Meteorologiczną (WMO) oraz Program Środowiskowy ONZ (UNEP). Siedzibą IPCC jest Genewa. Istotą działalności panelu jest opracowywanie raportów będących efektem pracy tysięcy naukowców o zróżnicowanych specjalnościach badawczych, rozsianych w instytucjach, uczelniach i laboratoriach zlokalizowanych na całym świecie, na temat stanu klimatu, przyczyn jego zmian oraz skutków, jakie one spowodują. W 1990 roku panel opublikował pierwszy raport dotyczący zagrożeń klimatycznych, wzywający do przygotowania globalnej konwencji w tym zakresie ${ }^{16}$. Kolejne raporty były publikowane w latach 1995 (II), 2001 (III), 2007 (IV) ${ }^{17}$. Warto pokrótce przyjrzeć się temu ostatniemu. Najważniejszą tezą zawartą w raporcie IV jest stwierdzenie, że prawdopodobieństwo, iż za zmiany klimatu odpowiadają czynniki naturalne wynosi $5 \%$, natomiast dla ich związku z antropogeniczną emisją gazów cieplarnianych — ponad $90 \%$. W raporcie wskazano także prognozę wzrostu temperatury w przedziale $1,8-4^{\circ} \mathrm{C}$ przy założeniu możliwych zmian w przedziale $1,1-6,4^{\circ} \mathrm{C}$.

Jeszcze bardziej dramatycznie przedstawiają się tezy raportu V (lata 20072013, publikowany w latach 2013-2014, przygotowany przez trzy grupy robocze):

- ocieplenie jest pewne,

- koncentracja dwutlenku węgla $\left(\mathrm{CO}_{2}\right)$ w atmosferze wzrosła o $40 \%$ względem ery przedprzemysłowej,

- globalna zmiana temperatury powierzchni Ziemi na koniec XXI wieku prawdopodobnie przekroczy $1,5^{\circ} \mathrm{C}$ względem okresu $1850-1990$.

9 maja 1992 roku w Nowym Jorku została sporządzona Ramowa Konwencja Narodów Zjednoczonych w sprawie Zmian Klimatu (United Nations Framework Convention on Climate Change). Podpisano ją 5 czerwca tegoż roku podczas tak zwanego Szczytu Ziemi w Rio de Janeiro (konferencja odbyła się w dwudziestolecie konferencji sztokholmskiej, czyli pierwszej konferencji o zasięgu globalnym

14 Dz.U. z 2015 r. poz. 881 ze zm.

15 W roku 2007 panel oraz wiceprezydent USA Al Gore za działania na rzecz ochrony klimatu otrzymali Pokojową Nagrodę Nobla.

16 J. Jendrośka, M. Bar, Prawo ochrony środowiska. Podręcznik, Wrocław 2005, s. 177.

17 Zob. R.K. Pachauri, A. Reisinger, Zmiana klimatu 2007. Raport Syntetyczny IPCC, Warszawa 2009, https://archive.ipcc.ch/pdf/reports-nonUN-translations/polish/Report\%20final\%20version.pdf (dostęp: 28.03.2020). 
poświęconej środowisku i jego ochronie), a weszła w życie 21 marca 1994 roku. Jest to pierwsza umowa międzynarodowa mająca na celu ochronę klimatu. Badania prowadzone przez panel jako źródło kryzysu klimatycznego jednoznacznie wskazują antropogeniczną emisję gazów cieplarnianych ${ }^{18}$. Główny cel konwencji został określony w art. 2 jako stabilizacja emisji gazów cieplarnianych na poziomie zapobiegającym antropogenicznemu wpływowi człowieka na system klimatyczny. Należy zaznaczyć, że w konwencji chodzi o stabilizację emisji, a nie ich redukcję. Konwencja dotyczy zatem zjawiska nazywanego globalnym ociepleniem, czasem mylonego z efektem cieplarnianym. Globalne ocieplenie jest bowiem skutkiem nadmiernej koncentracji ilości gazów cieplarnianych w atmosferze, co wzmacnia efekt cieplarniany (można je zatem nazwać efektem cieplarnianym plus). Badania prowadzone przez ICCP wskazują, że dzieje się tak wskutek spalania paliw kopalnych, co oznacza przenoszenie gazów cieplarnianych z rezerwuaru zamkniętego, jakim jest wnętrze Ziemi, do rezerwuaru otwartego, czyli atmosfery, ale także na skutek wycinania naturalnych pochłaniaczy $\mathrm{CO}_{2}$, czyli lasów. Konwencja podzieliła (co później okazało się jednym z jej istotnych mankamentów, lecz zapewne w realiach pierwszej połowy lat dziewięćdziesiątych XX wieku nie można było postąpić inaczej) państwa świata na trzy grupy: państwa uprzemysłowione, państwa w okresie transformacji ustrojowej (w tym Polska) oraz państwa rozwijające się. Do realizacji celów konwencji zobowiązano tylko państwa pierwszej i drugiej grupy. Państwa rozwijające się, w imię sprawiedliwości dziejowej, stały się beneficjentami działań podejmowanych przez kraje zobowiązane. Państwa intensywnie rozwijające swoje gospodarki, takie jak Chiny, Indie czy Brazylia, znalazły się w trzeciej grupie. Konwencja powołała również własne organy, z których najważniejszym jest Konferencja Stron Konwencji (dalej: COP), od 1995 roku zwoływana corocznie, zajmująca się monitorowaniem realizacji celów konwencji i opracowująca projekty ewentualnych nowych porozumień dotyczących ochrony klimatu ${ }^{19}$.

Dość szybko strony konwencji doszły do wniosku, że przyjęty cel to za mało, by powstrzymać kryzys klimatyczny. Podczas trzeciego COP w Kioto, w roku 1997, został przyjęty jeden z najsłynniejszych i najbardziej znanych aktów prawa międzynarodowego — protokół z Kioto do Ramowej Konwencji Narodów Zjednoczonych w sprawie Zmian Klimatu. Protokół szedł znacznie dalej niż konwencja - wyznaczonym celem nie była już bowiem stabilizacja emisji, lecz ich ilościowa redukcja. W pierwszym okresie rozliczeniowym wskazano poziom 5\% emisji z roku bazowego 1990. Stało się to przeszkodą do wejścia w życie proto-

18 Gazy cieplarniane składają się z cząstek zdolnych zatrzymywać część promieniowania cieplnego docierającego do Ziemi i odpowiadają za powstawanie efektu cieplarnianego, dzięki któremu temperatura powierzchni Ziemi umożliwia istnienie życia biologicznego w takim kształcie, jaki znamy. Zob. więcej: A. Kardaś, S. Malinowski, M. Popkiewicz, Nauka o klimacie, Warszawa 2019.

19 Z dotychczasowych dwudziestu pięciu COP trzy odbyły się w Polsce: czwarty w Poznaniu (2008), dziewiętnasty w Warszawie (2013) i dwudziesty czwarty w Katowicach (2018). 
kołu, który zaczął obowiązywać dopiero od 16 lutego 2005 roku i objął pierwszy okres rozliczeniowy, czyli lata 2008-2012, choć protokół został przyjęty na okres dziesięcioletni. Łącznie na podstawie konwencji i protokołu kontrolą objęto emisję sześciu gazów cieplarnianych: dwutlenku węgla $\left(\mathrm{CO}_{2}\right)$, metanu $\left(\mathrm{CH}_{4}\right)$, podtlenku azotu $\left(\mathrm{N}_{2} \mathrm{O}\right)$, fluorowęglowodorów (HFC, CHF) i perfluorowęglowodorów (PFC). Protokół wprowadził także specjalne mechanizmy osiągania celów redukcyjnych — zarówno indywidualnie przez poszczególne kraje, jak i łącznie. Przyjęto bowiem słuszne założenie, że nie ma znaczenia, gdzie jest osiągana redukcja — liczy się osiągnięcie zamierzonego celu redukcyjnego. Najważniejszym mechanizmem jest handel uprawnieniami emisyjnymi, który spowodował konieczność utworzenia nowych organów w strukturze. Aktualny status protokołu nie jest do końca jasny. Na konferencji w Dauha w 2012 roku uzgodniono przedłużenie jego obowiązywania do roku 2020. Jednak należy zaznaczyć, iż dotyczy on jedynie części krajów rozwiniętych, w związku z tym podkreśla się, ,że jego potencjalna skuteczność jest mocno wątpliwa"20. Unia Europejska jest bez wątpienia światowym liderem działań na rzecz ochrony klimatu i zobowiązała się do dalszego przestrzegania protokołu, co między innymi znalazło formalne potwierdzenie w Rozporządzeniu Komisji (UE) nr 389/2013 z dnia 2 maja 2013 roku ustanawiającym rejestr Unii zgodnie z dyrektywą 2003/87 (ustanawiającą system handlu przydziałami gazów cieplarnianych we Wspólnocie) Parlamentu Europejskiego i Rady, decyzjami nr 280/2004/WE i nr 406/2009/WE Parlamentu Europejskiego i Rady, uchylającym rozporządzenia Komisji (UE) nr 920/2010 i nr 1193/2011. To rozporządzenie zostało w ostatnim czasie zmienione rozporządzeniem z dnia 12 marca 2019 roku w odniesieniu do technicznego wykonania drugiego okresu rozliczeniowego protokołu z Kioto (co prawda weszło ono w życie 22 lipca 2019 roku, jednakże będzie stosowane od 1 stycznia 2021 roku).

Najnowszy program działań społeczności międzynarodowej został zawarty w paryskim porozumieniu klimatycznym ${ }^{21}$. Jest to umowa o charakterze globalnym przyjęta podczas COP w Paryżu 12 grudnia 2015 roku, wskazująca działania zmierzające do osiągnięcia głównego celu, określonego jako zatrzymanie globalnego ocieplenia na poziomie dużo poniżej $2^{\circ} \mathrm{C}$ względem poziomu z czasów przedprzemysłowych oraz staranie się, by było to nie więcej niż $1,5^{\circ} \mathrm{C}$. Porozumienie weszło w życie 4 listopada 2016 roku po spełnieniu warunku ratyfikowania przez co najmniej 55 krajów produkujących co najmniej 55\% globalnej emisji gazów cieplarnianych (podobny mechanizm był warunkiem wejścia w życie protokołu z Kioto). Na pewno plusem porozumienia jest sam fakt, że udało się je osiągnąć - może nie brzmi to optymistycznie, ale w przeciwnym razie Unia Europejska, stosując się w dalszym ciągu do postanowień protokołu, pozostała-

20 Tak Prawo ochrony środowiska..., s. 292.

21 Wszystkie informacje dotyczące porozumienia pochodzą ze strony: www.consilium.europa. $\mathrm{eu} / \mathrm{pl} /$ policies/climate-change. 
by samotną wyspą. Duże znaczenie ma również zniesienie stanu ustanowionego przez konwencję i protokół nakładającego obowiązki podejmowania działań na rzecz ochrony klimatu jedynie na państwa rozwinięte. Zgodnie z porozumieniem do takich działań zobowiązane są obecnie wszystkie kraje — poprzez redukcję emisji $\mathrm{CO}_{2}$ oraz zwiększanie jego pochłaniania, zwłaszcza przez zalesianie. Podstawowym mankamentem tego dokumentu wydaje się być brak wskazania ilościowych poziomów redukcji - przyjęto bowiem zasadę, że każde państwo będące stroną umowy samo określa jej docelowy poziom, a co więcej — porozumienie nie przewiduje sankcji (odwrotnie niż protokół) za niezrealizowanie zobowiązań. Zapewne właśnie taki „miękki” charakter umowy spowodował, że została przyjęta i weszła w życie.

Regulacje prawne ochrony klimatu wywarły i wywierają znaczący wpływ na działania Unii Europejskiej, Polski, na strukturę administracji i jej zadania. Przejawia się to przede wszystkim w określaniu różnorodnych strategii i programów działania mających na celu przygotowanie instytucji, społeczeństw oraz jednostek do adaptacji do nowych warunków i minimalizowania płynących z nich zagrożeń. W 2009 roku Unia Europejska przyjęła Białą księgę22 noszącą tytuł Adaptacja do zmian klimatu: europejskie ramy działania. Wskazano w niej szereg środków koniecznych do wdrożenia, by zrealizować główny cel: aby Europa była bardziej odporna na zmiany klimatu. Powinno to zostać osiągnięte przez zwiększenie gotowości i zdolności do reagowania na skutki zmian klimatu na szczeblu lokalnym, regionalnym, krajowym i unijnym, co będzie wymagało opracowania wspólnego podejścia i poprawy koordynacji działań podejmowanych na różnych szczeblach administracji. W kolejnej księdze, z 2013 roku, w zakresie przystosowania się do zmian klimatu, przewidziano opracowywanie planów adaptacyjnych do zmian klimatu w miastach powyżej stu tysięcy mieszkańców (MAP).

29 października 2013 roku Rada Ministrów przyjęła Strategiczny plan adaptacji dla sektorów wrażliwych na zmiany klimatu do roku 2020 z perspektywą do roku 2030 (SPA 2020)23. Jest to pierwszy w Polsce dokument strategiczny dotyczący adaptacji do zachodzących zmian klimatu, wskazujący zróżnicowane grupy działań adaptacyjnych w zakresie przedsięwzięć technicznych, infrastruktury przeciwpowodziowej, przyjmowania planów szybkiego reagowania, upowszechniania wiedzy na temat zmian klimatu i wynikających z nich zagrożeń. Został on opracowany na podstawie badań prowadzonych w ramach projektu Klimada, realizowanego na zlecenie Ministerstwa Środowiska w latach 2011-201324. Ważnym elementem SPA jest wskazanie na konieczność dokonania niezbędnych zmian obowiązującego prawa, zwłaszcza w obszarze planowania przestrzennego. Chodzi przede wszystkim o ograniczenie możliwości zabudowy terenów zagrożonych

22 eur-lex europa.eu $>$ legal-content $>$ ALL $>$ uri $=$ CELEX52009DC014.

23 Treść na stronie: www.mos.gov.pl.

$24 \mathrm{http} /$ /klimada.mos.gov.pl/zmiany-klimatu-w-polsce/projekty-badawcze/. 
powodziami i podtopieniami. Plan nie przewiduje utworzenia nowych struktur czy instytucji odpowiedzialnych za koordynację działań. Będą one podejmowane przez struktury objęte przede wszystkim systemem zarządzania kryzysowego funkcjonującym na podstawie ustawy z dnia 26 kwietnia 2007 roku o zarządzaniu kryzysowym $^{25}$. Miejskie plany adaptacji znalazły się w gestii jednostek samorządu terytorialnego. W obecnym stanie to rozwiązanie wydaje się właściwe, lecz w przyszłości, w związku z potencjalnym nasileniem się kryzysu klimatycznego, będzie potrzebna interwencja z poziomu administracji centralnej ${ }^{26}$. SPA nie ma charakteru normatywnego, jest dokumentem, który należy zaliczyć do planistycznych instrumentów ochrony środowiska.

Ochrona klimatu nie tylko przysparza i będzie przysparzała administracji, czy szerzej — władzom publicznym, nowych zadań, lecz także powoduje konieczność dokonywania, na określonym etapie, niezbędnych zmian strukturalnych. Ważne jest podkreślenie dynamizmu sytuacji — istniejące obecnie struktury za kilka czy kilkanaście lat mogą bowiem okazać się niewystarczające lub niewydolne.

W Unii Europejskiej zmiany spowodowane nadaniem ochronie klimatu swoistego priorytetu zostały odzwierciedlone w składzie drugiej Komisji Europejskiej kierowanej przez Joségo Manuela Durão Barroso, zatwierdzonej przez Parlament Europejski w lutym 2010 roku. Po raz pierwszy w historii Unii Europejskiej powołano komisarza do spraw klimatu, niezależnie od powoływanego od kilkudziesięciu lat komisarza odpowiedzialnego za ochronę środowiska. Została nim była duńska minister środowiska Connie Hedegaard. W aktualnej strukturze Komisji Europejskiej znajduje się Dyrekcja Generalna Klimat ${ }^{27}$ zajmująca się działaniami w zakresie ochrony klimatu w UE i prowadząca negocjacje międzynarodowe w tym obszarze w imieniu Unii.

W Polsce, wyłącznie ze względu na regulacje dotyczące ochrony klimatu, utworzono Krajowy system bilansowania i prognozowania emisji. Jak już wspomniano, jednym z mechanizmów osiągania celów protokołu jest handel uprawnieniami emisyjnymi. Obecnie akty prawa europejskiego dotyczące tego zagadnienia zostały implementowane przez ustawę z dnia 12 czerwca 2015 roku o systemie handlu uprawnieniami do emisji gazów cieplarnianych ${ }^{28}$ oraz ustawę z dnia 17 lipca 2009 roku o systemie zarządzania emisjami gazów cieplarnianych i innych substancji ${ }^{29}$. Na podstawie art. 3 ustawy o systemie zarządzania emisjami gazów cieplarnianych i innych substancji utworzono Krajowy ośrodek bilansowania i zarządzania emisjami (dalej: Kobize) odpowiadający za funkcjonowanie Kra-

25 Dz.U. z 2007 r. Nr 89, poz. 590 ze zm.

${ }^{26}$ Zauważono to w publikacji $O$ problemie większym niż gmina. Samorzad wobec zmian klimatycznych, [w:] Polska samorzadów. Silna demokracja, skuteczne państwo, red. D. Sześciło, Warszawa 2019 (www.batory.org.pl).

$27 \mathrm{https} / / \mathrm{ec}$. eu/info/departmens/climate-action_pl.

28 Dz.U. z 2015 r. poz. 1223 ze zm.

29 Dz.U. z 2009 r. Nr 130, poz. 1070 ze zm. 
jowego systemu bilansowania i prognozowania emisji. Na podstawie zaś art. 4 wspomnianej ustawy wykonywanie zadań Kobize zostało powierzone Instytutowi Ochrony Środowiska w Warszawie ${ }^{30}$. Ani Instytutu, ani tym bardziej Kobize nie da się zaliczyć do organów administracji w sensie ustrojowym. Mamy tu raczej do czynienia $\mathrm{z}$ administratorem systemu $\mathrm{w}$ sensie funkcjonalnym, odpowiadającym za jego działanie w zakresie określonym w ustawie, zarządzającym zbiorem rachunków w rejestrze Unii podlegających jurysdykcji Rzeczypospolitej Polskiej zgodnie z wspomnianym rozporządzeniem 389/2013.

Najbardziej spektakularna zmiana w strukturze administracji związana z ochroną klimatu nastąpiła w listopadzie 2019 roku, i to na szczeblu centralnej administracji rządowej, w związku powołaniem aktualnej Rady Ministrów. Po raz pierwszy w strukturze rządu znalazł się minister klimatu. Rozporządzeniem Rady Ministrów z dnia 19 listopada 2019 roku $^{31}$ dokonano zmiany rozporządzenia Rady Ministrów z dnia 26 października 1999 roku w sprawie utworzenia Ministerstwa Środowiska ${ }^{32}$, zmieniając nazwę „Ministerstwo Środowiska” na „Ministerstwo Klimatu”. Z kolei prezes Rady Ministrów rozporządzeniem z dnia 18 listopada 2019 roku w sprawie szczegółowego zakresu działania ministra klimatu wskazał go jako kierującego działem administracji rządowej — środowisko. Jednocześnie w skład Rady Ministrów został powołany minister, członek Rady Ministrów, któremu na podstawie rozporządzenia prezesa Rady Ministrów z dnia 18 listopada 2019 roku ${ }^{33}$ w sprawie szczegółowego zakresu działania ministra, członka Rady Ministrów, Michała Wosia, i na podstawie $\S 1$ rozporządzenia prezes Rady Ministrów powierzył prowadzenie spraw związanych z przygotowaniem propozycji podziału spraw objętych działem administracji rządowej „środowisko” pomiędzy ten dział administracji rządowej a projektowany dział administracji rządowej „klimat”. Sytuacja jest o tyle kuriozalna, że w ustawie o działach administracji rządowej ${ }^{34} \mathrm{z}$ dnia 4 września 1997 roku znajduje się dział „środowisko”, a nie ma działu „klimat”, istniało Ministerstwo Środowiska, a nie Ministerstwo Klimatu. Wydaje się, że chyba należało postąpić odwrotnie - nie przekształcać istniejącej struktury, lecz, wcześniej zmieniając w stosownym zakresie ustawę o działach administracji rządowej, utworzyć nowe ministerstwo i powierzyć je ministrowi do spraw klimatu.

Kryzys klimatyczny będzie wpływał na działania administracji w coraz większym stopniu. Na razie znajdujemy się na etapie już nie tylko diagnozy proble$\mathrm{mu}$, ale poszukiwania skutecznych środków zaradczych. Niewątpliwie postawi

${ }^{30}$ Instytut jest państwową jednostką naukowo-badawczą utworzoną na podstawie zarządzenia Ministra Ochrony Środowiska i Zasobów Naturalnych z dnia 1 kwietnia 1986 roku, działającą na podstawie ustawy z dnia 30 kwietnia 2010 roku O instytutach badawczych (Dz.U. z 2010 r. Nr 96, poz. 618), podległą ministrowi właściwemu do spraw środowiska.

31 Dz.U. z 2019 r. poz. 2289.

32 Dz.U. z 1999 r. Nr 91, poz. 1017.

33 Dz.U. z 2019 r. poz. 2276.

34 Dz.U. z 1997 r. Nr 141, poz. 943 ze zm. 
to przed organami administracji nowe problemy, będzie miało wpływ, zapewne coraz większy, na jej zadania i strukturę. Migracje, uchodźcy klimatyczni, bezpieczeństwo, handel, rolnictwo, produkcja żywności, zaopatrzenie w wodę, susze, powodzie, gwałtowne klęski żywiołowe związane ze zjawiskami meteorologicznymi wcześniej niewystępującymi na danych obszarach — to tylko część problemów, przed którymi stanie administracja. Może to powodować konieczność działania w stanie permanentnego kryzysu wymagającego powoływania na szczeblu centralnym i lokalnym specjalnych grup interwencyjnych, a nawet prowadzić do utraty zdolności do działania z powodu braku zasobów na obszarach, które stracą dotychczasowe zdolności funkcjonalne. Być może administrację dotknie zjawisko migracji urzędów w ślad za migracjami ludzi. Na pewno będzie potrzebny wysiłek edukacyjny zarówno w wymiarze społecznym, jak i jednostkowym ${ }^{35}$.

\title{
ADMINISTRATION TOWARDS CLIMATE CHANGE (PROLEGOMENA)
}

\author{
Summary
}

Global warming is recognised as the biggest problem facing humanity in the 21 st century. Legal rules aimed at counteracting the climate crisis or reducing its effect began to appear in the 1990s. This is related to the activities of the Intergovernmental Panel on Climate Change (IPCC), which led to the adoption in 1992 of the United Nations Framework Convention on Climate Change supplemented by the Kyoto accords. International, European, and national legal regulations aimed at climate protection imply a whole range of new tasks for public authorities. These rules also affect its structure and require the creation of new specialised bodies.

Keywords: public administration, climate change, global warming, climate convention

\section{BIBLIOGRAFIA}

Boć J., Nowacki K., Samborska-Boć E., Ochrona środowiska, Wrocław 2005.

Chajbowicz A., Bezpieczeństwo a pojęcia zbliżone, [w:] Bezpieczeństwo wewnętrzne $w$ działaniach terenowej administracji publicznej, red. A. Chajbowicz, T. Kocowski, Wrocław 2009.

Ciechanowicz J., Międzynarodowe prawo ochrony środowiska, Warszawa 1999.

Edukacja i świadomość ekologiczna, red. M. Pfeiffer, Poznań 1997.

Grochowska I., Benedykt XVI o powinności względem środowiska i integralnego rozwoju człowieka i ludów, [w:] Zmiany klimatu a społeczeństwo, red. L. Karski, I. Grochowska, Warszawa 2010. Grochowska I., Humanizacja w XXI wieku nowoczesnego podmiotu, „Studia Ecologiae et Bioethicae" 2004, nr 2.

Jendrośka J., Bar M., Prawo ochrony środowiska. Podręcznik, Wrocław 2005.

35 Zob. Edukacja i świadomość ekologiczna, red. A. Pfeiffer, Poznań 1997; P. Singer, Jeden świat. Etyka globalizacji, Warszawa 2006. 
Kardaś S., Malinowski M., Popkiewicz M., Nauka o klimacie, Warszawa 2019.

Karski L., Istota prawa zmian klimatu - cel i klasyfikacja, [w:] Zmiany klimatu a społeczeństwo, red. L. Karski, I. Grochowska, Warszawa 2010.

Korzeniowski P., Bezpieczeństwo ekologiczne jako instytucja prawa ochrony środowiska, Łódź 2012.

Mesarovic M., Pastel E., Ludzkość w punkcie zwrotnym. Drugi Raport dla Klubu Rzymskiego, Warszawa 1977.

Najder-Stefaniak K., Metanoia jako odpowiedź na etyczny wymiar kryzysu, [w:] Zmiany klimatu a społeczeństwo, red. L. Karski, I. Grochowska, Warszawa 2010.

O problemie większym niż gmina. Samorząd wobec zmian klimatycznych, [w:] Polska samorząów. Silna demokracja, skuteczne państwo, red. D. Sześciło, Warszawa 2019.

Pachauri R.K., Reisinger A., Zmiana klimatu 2007. Raport Syntetyczny IPCC, Warszawa 2009, https://archive.ipcc.ch/pdf/reports-nonUN-translations/polish/Report\%20final\%20version.pdf (dostęp: 28.03.2020).

Polska samorząów. Silna demokracja, skuteczne państwo, red. D. Sześciło, Warszawa 2019.

Prawo ochrony środowiska, red. M. Górski, Warszawa 2018.

Singer P., Jeden świat. Etyka globalizacji, Warszawa 2006.

Zmiany klimatu a społeczeństwo, red. L. Karski, I. Grochowska, Warszawa 2010. 